\title{
Wokół definicji parodii filmowej
}

Images

vol. XIV/no. 23

Poznań 2014

ISSN 1731-450X

W dziedzinie twórczości filmowej zjawisko parodii nie należy bynajmniej do nowych. Pojawia się ono na ekranie - w różnorodnych odmianach i formach - od ponad stu lat. Parodiowanie za pomocą ruchomych obrazów, początkowo występujące sporadycznie, przybrało z czasem kształt na tyle wyrazisty i stale obecny w kulturze filmowej kolejnych epok, że znajduje on wielorakie odzwierciedlenie w genologii historycznej kina. Parodia filmowa nazywana bywała bardzo różnie: "krotochwilą”, „farsą”, „komedią”, „groteską”, „burleską”, „satyrą”, „bufonadą" itp. W każdej z tych postaci zawiera się jednak pierwiastek parodystyczny jako istotny wyznacznik ich poetyki.

Nasuwa się w tym miejscu pytanie: czy parodia jest jednym $\mathrm{z}$ wielu gatunków filmowych? Zapewne jest nim (i tak też będziemy ją traktować), ale nie w rozumieniu, które odnosi się do melodramatu, filmu gangsterskiego, horroru czy westernu. Próba zdefiniowania pojęcia parodii i sporządzenia charakterystyki genologicznej jej właściwości prowadzi bowiem do wniosku, że mamy do czynienia z kategorią genologiczną szczególnego typu. Kategorią międzygatunkową i metagatunkową równocześnie - realizującą za każdym razem specyficzną postać intertekstualności. Parodia z natury swej pasożytuje na utworze filmowym dowolnego gatunku, wchodząc z nim w niszczące pierwowzór relacje symbiotyczne.

Na gruncie kultury filmowej określenie „parodia” pojawia się i funkcjonuje zazwyczaj jako nazwa metagatunku bądź też antygatunku, będącego - wyrażonym w przerysowany, ośmieszający, satyryczny sposób - naśladownictwem określonego dzieła, stylu, konwencji tematycznej, sposobu widzenia rzeczywistości, gatunku lub kierunku filmowego. Do kwestii tej powrócimy jeszcze szczegółowo w toku dalszych rozważań. Należy ona bowiem do kluczowych zagadnień poetyki parodii - i to zarówno poetyki historycznej, jak i poetyki opisowej - przesądzając ostatecznie o pełnionych przez nią funkcjach i charakterystyce gatunkowej.

Najłatwiej pomylić parodię z burleską filmową. Aby obie te kategorie od siebie oddzielić i w miarę precyzyjnie rozróżnić, trzeba najpierw zdefiniować kinową burleskę. Starsza od parodii, należąca do klasycznych gatunków filmowych burleska (z włoskiego burlesco 'zabawny', 'śmieszny', 'żartobliwy', ang., franc. burlesque) oznacza krótki utwór komiczny, często, choć niekoniecznie, o charakterze satyrycznym, oparty na zręcznie wydobywanym kontraście podniosłej tematyki i po-

Parodia a burleska

\section{Gatunek czy metagatunek?}


spolitego, trywialnego, niekiedy wulgarnego stylu, operujący elementami slapsticku, karykatury, błazenady i rubasznym poczuciem humoru.

Za absolutny początek dziejów tego gatunku uważane są Scènes burlesques devant un café, I-III, nakręcone przez braci Lumière w roku 1898. Mówimy w tym momencie o narodzinach burleski, a nie parodii. W pionierskim okresie rozwoju kinematografii burleska przeżyła niebywały w skali światowej boom, w ciągu zaledwie paru lat stając się jednym z najpopularniejszych gatunków kina. Cieszyła się w tamtym czasie ogromnym powodzeniem dzięki tysiącom filmów produkowanych po obu stronach Atlantyku.

W Europie twórcami jej sukcesu stali się przede wszystkim komicy: Max Linder, Robinette, Robinet i Fricot, Riri, Kri Kri, Polidor, André Deed (Cretinetti), Pat i Patachon oraz nasz rodzimy niekoronowany król farsy Antoni Fertner. W Ameryce promotorami burleski slapstickowej byli dwaj zawzięcie konkurujący z sobą producenci: Mack Sennett i Hal Roach. To im sztuka filmowa zawdzięcza odkrycie plejady wspaniałych aktorów, do których należą między innymi: Ford Sterling, Roscoe „Fatty” Arbuckle, Mabel Normand, Bobby Vernon, Charlie Chaplin, Harold Lloyd, Ben Turpin, Buster Keaton, Stanley Laurel, Oliver Hardy, Larry Semon, Billy Bevan, Mack Swann, Chester Conklin i Charley Chase.

W zaproponowanym tutaj rozumieniu parodia filmowa nie jest jednak burleską i nie powinna być z nią utożsamiana, choć we wczesnej fazie rozwoju sztuki ruchomych obrazów stylistyka burleski odegrała zasadniczą rolę w krystalizacji parodystycznych form i funkcji kina.

Parodia ery kina niemego
Współczesny kinoman, oglądający powiedzmy Robin Hooda: facetów w rajtuzach, Szklanka po łapkach, But Manitou, Wysyp żywych trupów czy Wampiry i świry, nie ma najczęściej żadnego pojęcia, iż parodię uprawiano z wielkim kunsztem i powodzeniem już w kinie niemym (Charlie Chaplin, Buster Keaton, Ben Turpin, Harry Langdon, Will Rogers i inni), a jej najstarsze - już wtedy mistrzowskie - wykonania sięgają drugiej dekady XX wieku. Jak przystało na historię filmu, bracia Lumière zostali przez nas obligatoryjnie wywołani i była mowa o ich prekursorskim wkładzie w rozwój parodii. Sam gatunek potrzebował jednak czasu, aby przemówić do masowej widowni z właściwą sobie atrakcyjnością.

U samych początków tej odmiany twórczości odnajdujemy filmową perełkę nakręconą przez hollywoodzką wytwórnię Keystone. Jest nią Help! Help! (1912), burleska slapstickowa będąca parodią wielkiego przeboju kinowego tamtej doby: starszego o trzy lata dramatu sensacyjnego Samotna willa w reżyserii Davida Warka Griffitha (1909). Wkrótce pojawiły się nowe. W Niemczech reżyser Emil Albes w krótkometrażówce pt. Der Andere - Student von Prague (1914) zaprezentował parodię Studenta $z$ Pragi Stellana Rye (1913).

W roku 1916 wytwórnia Keystone wyprodukowała parodię ekranizacji Enocha Ardena Griffitha (After Many Years, 1911) pod tytułem A Modern Enoch Arden (reż. Charles Avery, Clarence G. Badger). 
W tymże roku 1916 Charlie Chaplin w fenomenalnie dowcipny i przewrotny sposób sparodiował Thedę Barę w roli Carmen (reż. Raoul Walsh, 1915) oraz wielki hit kasowy Cecila Blounta DeMille'a Carmen (1915), ekranizację opery Georgesa Bizeta, w której wystąpiła słynna diva tamtych czasów Geraldine Farrar.

W nakręconej dla wytwórni Essenay parodii Charlie Chaplin's Burlesque on Carmen (1916) Chaplin nie tylko obsadził siebie w roli tytułowej, co przydało całości nieco perwersyjnego posmaku, ale przy okazji bezlitośnie wyśmiał także koturnowy charakter operowej konwencji. Wzniosłość i powaga poruszanego tematu stanowi jeden z ulubionych celów parodii, nie tylko filmowej. Kilka lat po Chaplinie jego utalentowany rywal Buster Keaton, przy współudziale reżyserskim Edwarda Cline’a, nakręcił - z sobą w roli głównej - doskonałą parodię Nietolerancji Griffitha (1916), nadając jej tytuł Trzy wieki (1923).

Trzecim znakomitym parodystą filmowym ery kina niemego był Ben Turpin, który zanotował na swoim koncie długi szereg znakomitych parodii. W roku 1919 zagrał Wuja Toma w parodii Uncle Tom Without a Cabin (reż. Edward F. Cline, Ray Hunt). Następnie jako Bill Poster, Szejk, wcielił się w rolę Rudolfa Valentino w The Shriek of Araby (reż. F. Richard Jones, 1923). Wystąpił też jako Romeo w parodii Romea i Julii (reż. Reggie Morris, Harry Sweet, 1924) i w roli nieustraszonego stróża porządku szeryfa Cyclone Billa w Yukon Jake (reż. Del Lord, 1924). Grając księcia Nikolo i niejakiego Rodneya St. Claira, Turpin mistrzowsko sparodiował również Ericha von Stroheima w When a Man's a Prince (parodia Szalonych żon, 1922, reż. Edward F. Cline, 1926) oraz Johna Gilberta w słynnej scenie miłosnej z udziałem muzyków w Stroheimowskiej ekranizacji Wesołej wdówki (A Prodigal Bridegroom, reż. Lloyd Bacon, Earle Rodney, 1926).

Galerię wspaniałych amerykańskich parodystów złotej ery kina niemego dopełnia czwarty z nich: Will Rodgers. Arcydzieło parodii filmowej dekady lat 20. stanowi Bez cenzury (Uncersored Movies, reż. Roy Clements, 1923). W filmie tym, wyprodukowanym przez Macka Sennetta, znalazła się antologia kapitalnych popisów parodystycznych w wykonaniu Rodgersa. Zagrał w nim między innymi: Forda Sterlinga jako nierozgarniętego szefa Keystone Cops, bohatera Dzikiego Zachodu Toma Mixa i swego przyjaciela Douglasa Fairbanksa w brawurowej parodii filmu Robin Hood (reż. Allan Dwan, 1922). W annałach historii tego gatunku pozostanie również westernowa parodia Karawany Jamesa Cruze (1923) z udziałem Rodgersa zatytułowana Two Wagons Both Covered (reż. Rob Wagner, 1924).

Wspólny dla różnych dziedzin kultury i sztuki oraz rozmaitych działań artystycznych i paraartystycznych mechanizm parodii polega za każdym razem na absolutnie koniecznym i nieodzownym przejaskrawieniu cech parodiowanego zjawiska. Warunek sine qua non każdej parodii, w tym także parodii filmowej, stanowią znamienne dla niej cechy: przekora, zaczepność, niestosowność, przesadne karykaturalne wyolbrzymienie, efekt komiczny i świadomie wykorzystana pars destru- 
ens. Generalny mechanizm parodii jest prosty. Memy parodiowanego pierwowzoru zostają wywołane ze zbiorowej pamięci po to, by poddać je perfidnemu procesowi destrukcji. Ich demontaż - dokonywany na oczach widza - prowadzi do ponownego montażu, odbierającego im pierwotne i nadającego nowe znaczenia.

Znaczeniodajny charakter parodii czerpie energię z zamierzonej dwuznaczności wykorzystanych przedstawień. Rozpoznawalne elementy parodiowanego obiektu muszą się pojawić i są w niej obecne, zostają jednak przywołane w odmiennym niż pierwotny sensie. Kapitalna rola przypada $\mathrm{w}$ tym procesie szeroko rozumianym operacjom montażowym. Przewrotnie i podstępnie naśladując manierę stylistyczną danego twórcy, wyszydzając skostniałe wzorce gatunkowe, nicując matryce fabularne i klisze tematyczne, rozbijając zużyte sztance, prześmiewając znane konwencje, utarte schematy i normy filmowej komunikacji, a także ostentacyjnie odrzucając cudzy sposób widzenia rzeczywistości parodia toruje drogę zarówno nowym procesom w życiu społecznym, jak i oryginalnym zjawiskom w sztuce i kulturze.

Powtarza w ten sposób i odświeża istniejące $z$ dawien dawna źródła parodii nie tylko nowożytnej (Boccaccio, Cervantes, Rabelais, Molière, Swift, Gay, Fielding, Pope, Diderot, Voltaire, Krasicki i inni), ale także antycznej. W kulturze starożytnej występowała ona między innymi: u Lukiana z Samosat, w komedii staroattyckiej (jako wyrafinowanej parodii tragedii greckiej), w przeróbce Gigantomachii autorstwa Hipponaksa z Efezu i Hegemona z Tazos, w poematach heroikomicznych (Batrachomachia) czy w satyrze menippejskiej. Osobną uwagę poświęcił temu gatunkowi Arystoteles na kartach Poetyki. Jak z powyższego skrótowego przypomnienia wynika, samo zjawisko prefilmowej parodii ma niezwykle szacowną i długą tradycję.

Kino odegrało i nadal odgrywa w ramach tego makroprocesu eksponowaną rolę jednego z najważniejszych terytoriów występowania parodii. Wiemy już, że historia parodii filmowej sięga odległych początków kinematografii. Oprócz przywołanych wcześniej filmów: Help! Help!, Carmen, Trzy wieki oraz Wuj Tom bez chaty, do klasycznych przykładów parodii w erze kina niemego należą ponadto: Pasierb Marsa (1914) Władysława Starewicza jako satyra polityczna wymierzona $\mathrm{w}$ wizerunek wojowniczego cesarza Wilhelma II oraz Zręczny muszkieter (1922) Maxa Lindera wobec Dwunastu diamentów (oryg. The Three Musketeers, 1921) Freda Niblo.

Parodia w kinie
dźwiękowym
Zupełnie nowy wyraz nadali zjawisku parodii filmowej bracia Marx. Początki ich twórczości zbiegły się z przełomem dźwiękowym. Oryginalność brawurowych dokonań parodystycznych Marxów polegała przede wszystkim na stworzeniu własnej niepowtarzalnej wizji świata na opak. Parodie z ich udziałem ukazywały rzeczywistość à rebours: świat zaludniony postaciami tworzącymi galerię figur, doskonale rozpoznawalnymi dla widza ze względu na ich od dawna kursujący w społecznym obiegu stereotypowy wizerunek. 
Tak właśnie prezentuje się cała reszta, podczas gdy Groucho, Chico i Harpo prowadzą w każdej scenie przewrotną grę z własnym i cudzym stereotypem wizerunkowym: amerykańskiego imigranta, pasażera, człowieka znikąd, bywalca, łowcy posagów, prostaka, snoba, self-made-mana, człowieka z eleganckiego świata, dyktatora, obdartusa, wieśniaka, milionera bez grosza, pomyleńca itp. Nie wszystko wymyślali oni sami. Niezwykle dowcipnych gagów oraz pamiętnych kwestii dialogowych dostarczali Marxom znakomici humoryści tamtej doby: Sidney Joseph Perelman, Arthur Sheekman, Morrie Ryskind, Will B. Johnstone, George S. Kaufman i Bert Kalmar.

Na początku lat 30. - niemalże w tym samym momencie, kiedy bracia Marx pracowali nad Kacza zupq - parodia została z powodzeniem wykorzystana w animacji. Animowana parodia znanej baśni nakręcona przez braci Fleischerów uchodzi za późniejszą od Królewny Śnieżki Walta Disneya. Tymczasem jest od niej całe cztery lata starsza i o niebo bardziej atrakcyjna, bo nader frywolna pod względem obyczajowym. Jej ekranowy tytuł brzmiał: Betty Boop in Snow-White (1933).

Całość trwa na ekranie siedem minut. Rolę producenta kreskówki pełnił Max Fleischer, reżyserował Dave Fleischer, twórcą kapitalnej animacji był stały współpracownik braci, mistrz nad mistrzami, Roland C. Crandall. Bracia Fleischerowie i Crandall wpadli na znakomity pomysł, aby w kulminacyjnej scenie niedoszłego pogrzebu bohaterki w grocie siedmiu krasnoludków wykorzystać bardzo wtedy popularny za sprawą fenomenalnej interpretacji Louisa Armstronga - standard jazzowy St. James Infirmary Blues, angażując jako wykonawcę (wokalistę i tancerza) - aranżera i dyrygenta, młodego Caba Callowaya.

W tytułową „Snow-White” z perwersyjnym wdziękiem wcieliła się na ekranie emanująca sex appealem prowokatorka Betty Boop. Już samo połączenie dwóch tak odmiennych postaci w jedną stanowiło wyzwanie. Niczym jej równie prowokacyjna konkurentka Mae West, Betty Boop w roli Królewny Śnieżki z upodobaniem gra tutaj na nerwach stróżom moralności. Grzeszna niewinność i niewinna zmysłowość tej postaci zwróciła uwagę oburzonych cenzorów, choć w czołówce filmu widnieje napis z wizą: „Passed by The National Board of Review”.

$\mathrm{Z}$ formalnoprawnego punktu widzenia uczyniono wszystko, aby uniknąć kłopotów cenzuralnych. A jednak figlarna Betty Boop wpadła w tarapaty. I nic dziwnego, bowiem Fleischerowska Snow-White była zdecydowanie Królewną Śnieżką dla dorosłych, co wkrótce miało jej przysporzyć niemałych problemów w drodze na ekrany kin zarówno w Ameryce, jak i na świecie. Z tego też względu ów niekwestionowany majstersztyk filmu rysunkowego ery wczesnodźwiękowej przez wiele następnych lat znany był jedynie wąskiemu gronu koneserów sztuki animacji filmowej.

Premiera Snow-White odbyła się 31 marca 1933 roku, na moment przed wprowadzeniem Kodeksu Produkcyjnego Haysa. To właśnie w tym filmie Fleischer wpadł na pomysł klipu, w którym KoKo the Clown wykonuje St. James Infirmary Blues w trakcie groteskowej ceremonii pogrzebowej Śnieżki. Pomysł był zaiste przewrotny. Na ekranie 
KoKo śpiewa S.J.I. przenikliwym głosem Caba Callowaya, wykonując jednocześnie taneczną parodię jego słynnych powłóczystych kroków i akrobatycznych wygibów. Dzięki twórczemu wykorzystaniu musicalowej polifonii sztuk miniaturowa całość należy do największych osiągnięć poetyki kina wczesnodźwiękowego.

Najpierw na ekranie pojawia się rozmawiająca ze swym zwierciadłem Zła Królowa, którą odwiedza seksowna pasierbica. Następnie widzimy scenę, w której śliczna Betty Boop zostaje skazana na śmierć przez okrutną macochę, będącą zazdrosną właścicielką magicznego lustra. Tymi, którzy mają wykonać egzekucję, okazują się KoKo i Bimbo, obaj zakuci w rycerskie hełmy i zbroje. Przywiązana do drzewa na mrozie królewna błaga o ratunek. Ocala swe życie, gdy wolność przywraca jej litościwe drzewo, do którego została przywiązana. Tocząc się i koziołkując po ośnieżonym zboczu, drogą paru metamorfoz, pogrążona we śnie wewnątrz lodowego sarkofagu, wpada prosto do groty siedmiu krasnoludków. St. James Infirmary Blues śpiewany przez klowna KoKo rozbrzmiewa w momencie, gdy w grocie pojawia się Zła Królowa, by osobiście sprawdzić wykonanie swego rozkazu.

Półtoraminutowa parodia pogrzebu Śnieżki skrzy się od kapitalnych, iście surrealistycznych pomysłów Fleischera i Crandalla. Na pierwszym planie oglądamy w niej kuriozalną ceremonię pogrzebową, która staje się pełnym wigoru hymnem na cześć życia. Posępny song zaczyna śpiewać KoKo, ale starucha zamienia go swym zwierciadłem w animowaną karykaturę Caba Callowaya i odtąd to on tańczy i śpiewa St. James Infirmary Blues w asyście Bimbo. Nieboszczka Betty Boop, na wieki zahibernowana w swej przezroczystej lodowej trumnie niesionej przez siedmiu krasnoludków, nie tylko nadal żyje, ale smacznie śpi w czarnej sukience mini, eleganckich bucikach i z głową na poduszce, od czasu do czasu trzepocząc rzęsami i obracając się we śnie na bok.

Jak nietrudno się domyślić, cała opowieść zmierza wprost do finałowego happy endu, w którym KoKo, Bimbo i Betty, pozbywszy się zamienionej w poczwarę prześladowczyni, tańczą radośnie we troje, trzymając się za ręce. Mistrzostwo autorów objawia się też w drugim planie kreskówki, w której ogromną rolę odgrywa aktywne tło. To w nim do głosu dochodzi w tej dwuznacznej baśni świat przedstawiony St. James Infirmary Blues. Tworzy go mroczny fresk ukazujący jaskinię występku i hazardu.

Sekwencja S.J.I. w Królewnie Śnieżce trwa zaledwie jedną minutę i czterdzieści sekund. Jej kwintesencję stanowi iście wisielczy humor. Całość doskonale koresponduje z posępną aurą Wielkiego Kryzysu i rozpadu społeczeństwa. Cab Calloway śpiewa i tańczy w sposób groteskowo przejaskrawiony i przerysowany. Uderza drapieżność przedstawionej wizji świata. St. James Infirmary Blues w jego kapitalnej interpretacji, nie przestając być bluesem, pozwala domyślać się inspiracji songami z Opery za trzy grosze. Dzięki przemyślnemu skumulowaniu energii filmowych efektów animowana miniatura osiąga niezwykłą dynamikę audiowizualnego kształtu. 
Jedną z wyrazistych odmian parodii filmowej stanowią parodie antytotalitarne (antykomunistyczne, antynazistowskie, antyfaszystowskie, okupacyjne etc.). Na miano prekursora tej odmiany parodii zasługuje Ernst Lubitsch najpierw jako twórca Ninotchki (1939), a następnie Być albo nie być (1942; jego remake nakręcił Mel Brooks w roku 1983). Wśród klasycznych przykładów parodii antytotalitarnych eksponowane miejsce zajmują: Dyktator (1940) Charliego Chaplina oraz nieco zapomniana dzisiaj krótkometrażówka Mówią Niemcy (1941) Lena Lye’a, będąca kapitalną parodią montażową hitlerowskich kronik propagandowych. Kino powojenne dołożyło do tej listy szereg dalszych filmów fabularnych produkcji: czeskiej (Nikt nic nie wie Josefa Macha, 1947), polskiej (okupacyjne partie Zezowatego szczęścia Andrzeja Munka, 1960; Giuseppe w Warszawie Stanisława Lenartowicza, 1964), francuskiej (Czarny rynek w Paryżu, reż. Claude Autant-Lara, 1956; Wielka włóczęga, reż. Gérard Oury, 1966), włoskiej (Życie jest piękne Roberta Begniniego, 1997) etc. Trzeba też wspomnieć brytyjski serial telewizyjny 'Allo Allo! (reż. David Croft, Jeremy Lloyd, 1982-1992).

Do innych najbardziej znanych parodii kina dźwiękowego należą: Oklahoma Woman (1956) Rogera Cormana, parodia The Oklahoman (1956) Francisa D. Lyona; Fernand Cowboy (1956) Guy Lefranca, Lemoniadowy Joe (1964) Oldřicha Lipskýego, Kasia Ballou (1965) Elliota Silversteina i Płonace siodła (1974) Mela Brooksa oraz Sułtani westernu (1991) Rona Underwooda jako parodie formuły gatunkowej westernu; Bierz forsę i w nogi (1969) i Banany (1971) Woody'ego Allena, będące parodiami: konwencji filmu gangsterskiego i biograficznych dokumentów telewizyjnych o południowoamerykańskich dyktatorach; Młody Frankenstein (1974) i Kosmiczne jaja (1987) Mela Brooksa parodiujące schematy gatunkowe horroru i filmu science fiction; Robin Hood: faceci $w$ rajtuzach (1993) również Mela Brooksa, parodia Robin Hooda: księcia złodziei (1991) Kevina Reykiego; Szpiedzy tacy jak my (1985) Johna Landisa; Szklanka po łapkach (1996) Ricka Friedberga, parodia Szklanej pułapki (reż. John McTiernan, 1988) i jej sequeli oraz konwencji gatunkowych współczesnego filmu akcji i in.

W kręceniu parodii wyspecjalizował się również tercet scenariopisarsko-reżyserski: Jim Abrahams, Jerry Zucker, David Zucker, mający na własnym koncie takie kasowe przeboje, jak: Czy leci z nami pilot? (1980) czy brawurowa Naga broń I-III $(1988,1992,1994)$. Klasą dla siebie jest reżysersko-aktorski majstersztyk Woody’ego Allena Zelig (1983), zawierający niebywale pomysłową i finezyjnie zmontowaną parodię konwencji dokumentu biograficznego, która czerpie inspirację zarówno z poetyki kina niemego, jak i dźwiękowego.

Przywołany został przed chwilą - znany dzisiaj kinomanom na całym świecie - Lemoniadowy Joe. Ale kinematografia dawnej Czechosłowacji wyprodukowała ponadto wiele innych znakomitych parodii filmowych. Pisze o nich szczegółowo w tym numerze „Images” znakomity znawca tematu Petr Mareš, oferując Czytelnikom pierwszą w literaturze przedmiotu syntezę ewolucji wątków parodystycznych w powojennym 
kinie czeskim, które niegdyś w znacznym stopniu przyczyniły się do nadania mu charakterystycznego stylu.

Spośród wielu nurtów parodii filmowo-telewizyjnej jednym ze szczególnie ważnych jest nurt anglosaski. Jego korzenie kulturowe sięgają kultury dziewiętnastowiecznego brytyjskiego music-hallu, pamfletu i karykatury prasowej. Z tradycji tej wyrasta zarówno telewizyjna parodia w burleskowym wydaniu Benny Hill Show, jak i surrealistyczny Latający Cyrk Monty Pythona, który oprócz cieszącego się od końca lat 6o. niesłabnącą popularnością cyklu programów telewizyjnych wyprodukował również takie znane na całym świecie filmowe parodie, jak: Monty Python i Święty Graal (reż. Terry Gilliam, Terry Jones, 1975), Żywot Briana (reż. Terry Jones, 1979) oraz Sens życia według Monty Pythona (reż. Terry Gilliam, Terry Jones, 1983).

Parodia w kinie polskim
Tak się z różnych powodów złożyło, że nasi filmowcy raczej stronili od parodii, niż z powodzeniem eksploatowali ten metagatunek. Niewątpliwym wkładem naszego kina do dziejów parodii, który mógłby znaleźć miejsce w każdej światowej antologii, jest Dwanaście krzeset (1933) według Ilfa i Pietrowa w polsko-czeskiej reżyserii Maca Friča i Michała Waszyńskiego oraz kapitalna sekwencja występu Eugeniusza Bodo w farsie filmowej Leona Trystana Piętro wyżej (1937). W filmie tym Bodo przebrany za efektowną kobietę w sile wieku wykonuje piosenkę Sex appeal, parodiując w niezwykle zabawny sposób seksbombę tamtych czasów Mae West. Rzecz dzieje się na balu kostiumowym. Adoratorem gwiazdy wieczoru, zafascynowanym jej obfitymi wdziękami, jest starszy pan (Józef Orwid) przebrany za rycerza w średniowiecznej zbroi i hełmie. Poza tym pikantnym obyczajowo fragmentem, należącym do większej nieparodystycznej całości, trudno byłoby wskazać inne reprezentatywne przykłady rodzimej parodii filmowej nakręcone przed wojną.

Na gruncie polskim parodia filmowa stanowi do tej pory niemałą rzadkość, co nie znaczy, że w ogóle u nas nie występuje. Jej pojawienie się należy historycznie wiązać z przełomem październikowym. Reprezentatywnego przykładu rozwiniętej parodii dostarcza Popiół i diament (1958) Andrzeja Wajdy, zawierający szyderczy portret zbiorowy polskiego społeczeństwa w roku 1945. Nieopisany dotąd pierwiastek parodystyczny kryje w sobie wczesna twórczość filmowa Jana Lenicy: począwszy od Nagrodzonego uczucia (1957, wspólnie z Walerianem Borowczykiem), poprzez Pana Głowę (1959), Nowego Janka Muzykanta (1960), Labirynt (1962) i A (1964), aż po Adama 2 (1968).

Reżyserem głęboko zafascynowanym możliwościami tej formy filmowej był Andrzej Munk (Eroica, 1957; wspomniane wcześniej Zezowate szczęście, 1960). Warto w tym miejscu przywołać znakomitą parodię Polskiej Kroniki Filmowej nakręconą przez niego w roku 1959 i opatrzoną wymownym parodystycznym podtytułem Wydanie (anty) jubileuszowe (PKF 1959, nr 51-52). Parodie spotykamy również wśród etiud studentów łódzkiej Szkoły Filmowej. Należą do nich między 
innymi: Hamleś Jerzego Skolimowskiego (1960), Ech (film dyplomowy Marka Koterskiego, 1972) oraz Magia kina Wojciecha Biedronia (1986).

W roku 1989 wszedł na ekrany Łabędzi śpiew w reżyserii Roberta Glińskiego (według scenariusza Bolesława Michałka, 1988) - inteligentna parodia klisz, stereotypów i obiegowych konwencji polskiego (i nie tylko polskiego) kina. Reżyserem wykazującym szczególną predylekcję do parodii jest wspomniany przed momentem Marek Koterski jako autor: Domu wariatów (1984), Dnia świra (2002) oraz Wszyscy jesteśmy Chrystusami (2006).

Od czasu do czasu kręcono u nas parodie społeczno-polityczne, zarówno dokumentalne, jak i fabularne, do których zaliczają się: Pożar! Pożar! Coś nareszcie dzieje się (1967), Hair (1971), Bulgot (1982) i Krok (1997) Marka Piwowskiego, Wahadełko (1981) Filipa Bajona, Mięso. Ironica (1993) Piotra Szulkina oraz Człowiek z... (1993) Konrada Szołajskiego. Oprócz Piwowskiego i Koterskiego klasą dla siebie i niedoścignionym specjalistą od parodii filmowej w kinematografii polskiej pozostaje od lat Juliusz Machulski jako autor: Seksmisji (1983), Kingsajz (1987), Déjà vu (1989), Kilera (1997), Superprodukcji (2003) oraz Ambassady (2013). Pozostałe, niezbyt zresztą liczne, przykłady polskiej fabularnej parodii filmowej jak dotąd nie przekonują swym poziomem na tyle, by wzmiankować ich tytuły w niniejszym przeglądzie.

Współczesny stan rozwoju gatunku parodystycznego z jednej strony eksploatuje dawne schematy parodii filmowej, z drugiej - próbuje poszerzać pole eksploracji o coraz to nowe konwencje, tematy i gatunki kina. W swych najlepszych realizacjach wykracza ona daleko poza formułę trywialnej imitacji wzorca, typową dla serii Straszny film I-V (2000-2013), reżyserowanej najpierw przez Keenana Ivory Wayansa (Scary Movie I-II) i Davida Zuckera (III-IV), a ostatnio przez Malcolma D. Lee (V, 2013). Parodie w takim, jak wspomniane tutaj, niewyszukanym wydaniu nadal powstają. Okazują się one jednak produkcjami tuzinkowymi, cierpiącymi przede wszystkim na deficyt nośnych pomysłów.

Punktem zwrotnym, który dostarczył współczesnej parodii cennych impulsów, stało się nakręcone dwie dekady temu Strzelając śmiechem w reżyserii Gene’a Quintano (1993), znane również w Polsce pod alternatywnym tytułem ekranowym $W$ krzywym zwierciadle. Przedmiotem parodystycznych zabiegów Strzelając śmiechem nie był jakikolwiek pojedynczy film, lecz - jak niegdyś u Willa Rodgersa łańcuch kunsztownie splecionych z sobą tekstowych i metatekstowych odniesień, tworzący rodzaj antologii parodii. Sama konstrukcja tej antologii nawiązuje do najlepszych tradycji kina sprzed dziesiątek lat. W ślad za filmem Quintano pojawiły się kolejne parodie nowej i najnowszej generacji, zdobywając na świecie znaczną popularność i uznanie kinomanów.

Kino amerykańskie nie jest dzisiaj bynajmniej monopolistą w dziedzinie parodii filmowej. Wprawdzie absolutną większość tytułów

Parodia w kinie współczesnym 
niniejszego przeglądu stanowią filmy amerykańskie, jednak oprócz nich znaczącą pozycję w dziejach tego gatunku uzyskały także produkcje: niemieckie, francuskie, hiszpańskie, włoskie, czeskie i inne.

Do najciekawszych przykładów parodii filmowej ostatnich dwóch dekad, oprócz wspomnianego Strzelając śmiechem, należy zaliczyć: Człowieka, który widział za dużo w reżyserii Jona Amiela (1997), To nie jest kolejna komedia dla kretynów (reż. Joel Gallen, 2008), niemiecki But Manitou (reż. Michael Herbig, 2001), brytyjski Wysyp żywych trupów (reż. Edgar Wright, 2004), Jaja w tropikach (reż. Ben Stiller, 2008), Komedia romantyczna (2006), Totalny kataklizm (2008), Poznaj moich Spartan (2008), Wampiry i świry (2010) - wszystkie w reżyserii Jasona Friedberga i Aarona Seltzera oraz Kaboom (reż. Gregg Araki, 2010). Ewenementem światowego formatu i klasą dla siebie stał się w ostatnim czasie Django w reżyserii Quentina Tarantino (2012), kumulujący w sobie najlepsze cechy i atrakcje nowoczesnej parodii filmowej. 